\title{
DIAGNOSIS OF HISTOPLASMOSIS
}

\author{
Allan Jefferson Guimarães ${ }^{1,2}$; Joshua D. Nosanchuk²; Rosely Maria Zancopé-Oliveira ${ }^{1 *}$ \\ ${ }^{1}$ Serviço de Micologia, Departamento de Micro-Imuno-Parasitologia, Instituto de Pesquisa Evandro Chagas, Fundação \\ Oswaldo Cruz, Rio de Janeiro, Brasil; ${ }^{2}$ Department of Medicine (Division of Infectious Diseases) \& Microbiology and \\ Imunology, Albert Einstein College of Medicine of Yeshiva University, Bronx, New York \\ Submitted: January 31, 2006; Approved: February 13, 2006
}

\begin{abstract}
Endemic mycoses can be challenging to diagnose and accurate interpretation of laboratory data is important to ensure the most appropriate treatment for the patients. Although the definitive diagnosis of histoplasmosis (HP), one of the most frequent endemic mycoses in the world, is achieved by direct diagnosis performed by micro and/or macroscopic observation of Histoplasma capsulatum (H. capsulatum), serologic evidence of this fungal infection is important since the isolation of the etiologic agents is time-consuming and insensitive. A variety of immunoassays have been used to detect specific antibodies to $H$. capsulatum. The most applied technique for antibody detection is immunodiffusion with sensitivity between 70 to $100 \%$ and specificity of $100 \%$, depending on the clinical form. The complement fixation (CF) test, a methodology extensively used on the past, is less specific (60 to $90 \%$ ). Detecting fungal antigens by immunoassays is valuable in immunocompromised individuals where such assays achieve positive predictive values of $96-98 \%$. Most current tests in diagnostic laboratories still utilize unpurified antigenic complexes from either whole fungal cells or their culture filtrates. Emphasis has shifted, however, to clinical immunoassays using highly purified and well-characterized antigens including recombinant antigens. In this paper, we review the current conventional diagnostic tools, such as complement fixation and immunodiffusion, outline the development of novel diagnostic reagents and methods, and discuss their relative merits and disadvantages to the immunodiagnostic of this mycosis.
\end{abstract}

Key words: diagnostic tests, culture based methods, molecular methods, serology

\section{INTRODUCTION}

Histoplasmosis is a systemic disease caused by the fungus Histoplasma capsulatum $(21,32,97)$. Human histoplasmosis is due to two varieties of the pathogen, Histoplasma capsulatum var. capsulatum and Histoplasma capsulatum var. duboisii. Both varieties are heterothallic and compatible (+) and (-) mating types unite to form the ascomycetous perfect stage designated Ajellomyces capsulatum. H. capsulatum var. capsulatum is the causative agent of classical histoplasmosis $(16,86,87,99)$. Less commom, H. capsulatum var. duboisii is the etiologic cause for African histoplasmosis $(33,87)$. H. capsulatum is thermally dimorphic (94). The fungus is primarily a mould in the environment, as a saprophytic organisms in soils enriched with organic nitrogen sources like animal excrements, or when grown in the laboratory at less than $35^{\circ} \mathrm{C}(3,29,40-43,124,125,159)$ (Fig. 1a). In contrast, the pathogenic single, budding yeast-like form is predominately isolated from infected tissue specimens and occurs when the microbe is grown at $37^{\circ} \mathrm{C}$ in the laboratory $(66,124,125)$ (Fig. 1b).

Histoplasmosis is a cosmopolitan mycosis with areas of particularly high endemicity. In North America, the endemic regions are in the Midwestern and Southeastern of United States $(1,53,136)$. In Latin America, the most prevalent areas are

*Corresponding Author. Mailing address: Corresponding author. Mailing address: Serviço de Micologia, DEMIP, Instituto de Pesquisa Clínica Evandro Chagas, Fundação Oswaldo Cruz. Av. Brasil 4365, Manguinhos, Rio de Janeiro 21045-900 Brazil. Tel.: (+5521) 3865-9557. Fax: (+5521) 2590-9988.

E-mail: zancope@ipec.fiocruz.br 

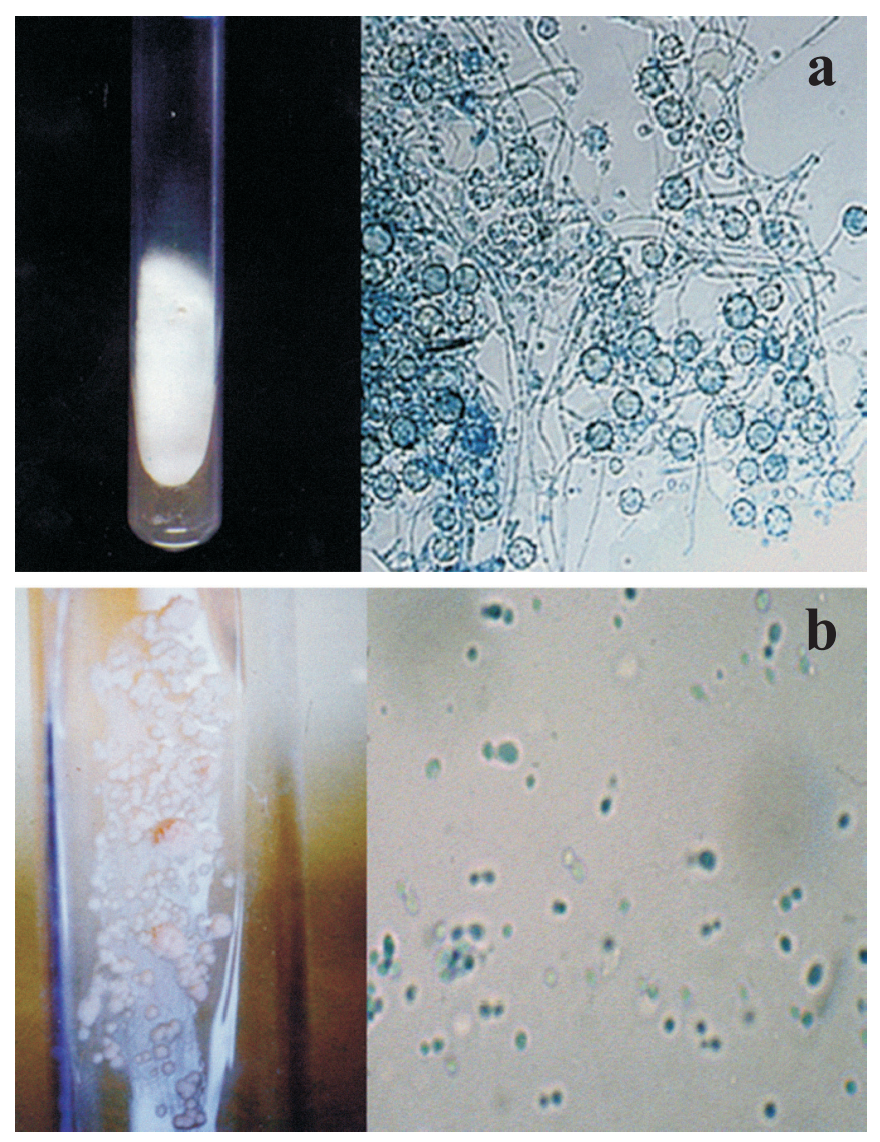

Figure 1. Histoplasma capsulatum: a) mold form (culture and microscopy); b) yeast form at $37^{\circ} \mathrm{C}$ (culture and microscopy respectively).

in Venezuela, Ecuador, Brazil, Paraguay, Uruguay and Argentina $(13,136,140)$ (Fig. 2). In Brazil, endemic areas are located in the Midwestern and Southeastern portions of the country, where the prevalence ranges from $4.4-63.1 \%$ and $3.0-93.2 \%$, respectively (Table 1 - Fig. 3) (91,157). Generally, the environmental conditions present in areas of high endemicity are a moderate climate with constant humidity (94).

Infection with H.capsulatum usually occurs by the inhalation of microconidia by the host, deposit in alveoli and rapidly convert to a parasitic yeast form in tissues. This germination and conversion can occur prior to or after ingestion by pulmonary macrophages $(2,19)$. Conidia and yeasts are ingested by macrophages and reticuloendothelial cells where the organism can survive within phagolysosomes (2). Once within the macrophage, the yeast multiply and travel to hilar and mediastinal lymph nodes where they gain access to the blood circulation for dissemination to various organs (141). The clinical manifestation of histoplasmosis range from asymptomatic infection to disseminated sepsis $(16,20,53,99,134)$. These manifestations

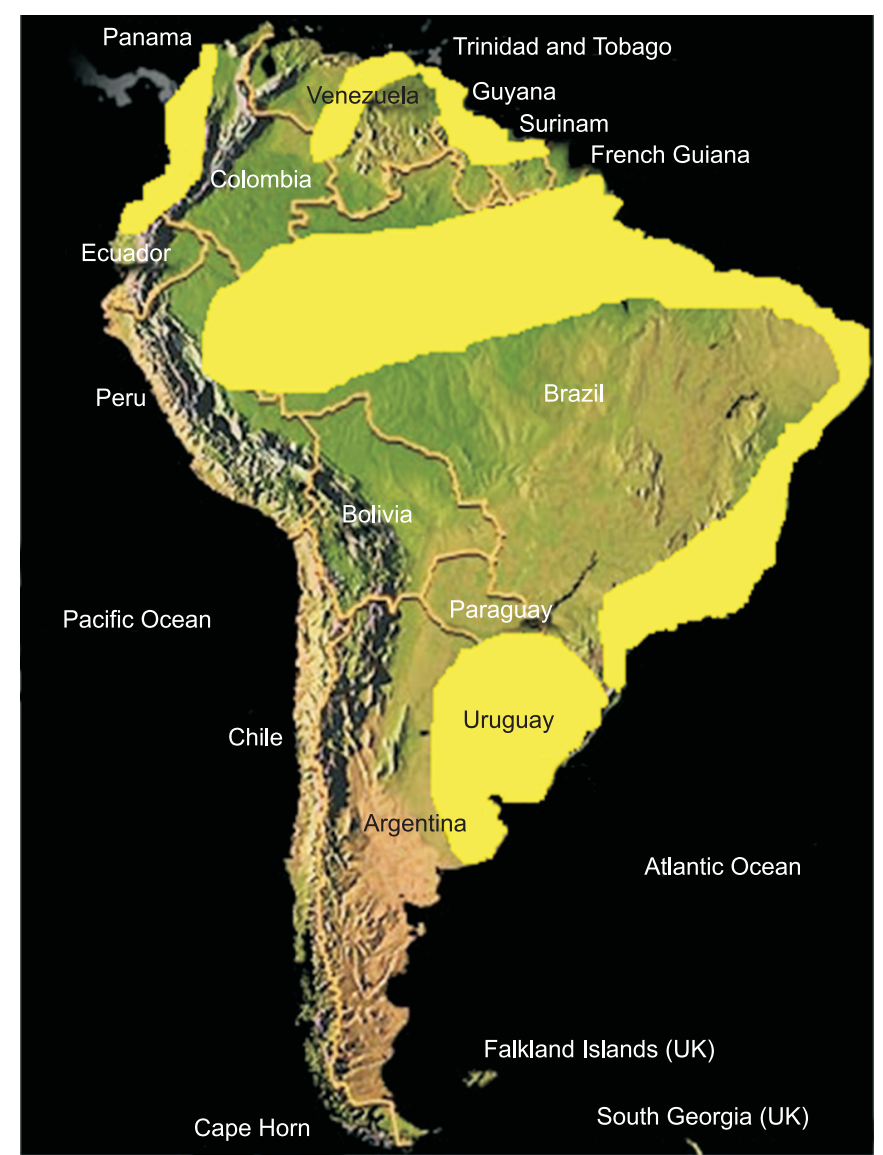

Figure 2. Distribution of histoplasmosis in South America.

Table 1. Epidemiologic distribution of histoplasmosis in Brazil, according to the reactivity pattern of skin test using histoplasmin.

\begin{tabular}{cc}
\hline Regions & Percentage of positive reaction \\
\hline North & $12.8-43.4$ \\
North East & $2.6-29.8$ \\
Middle West & $4.4-63.1$ \\
South East & $3.0-93.2$ \\
South & $6.3-16.0$ \\
\hline
\end{tabular}

depend mainly on the magnitude of exposure (i.e. the number of fungal particles inhaled), the immunological status of the host, and the virulence of the infective strain, indicating that environmental and genetic factors control the manifestation of disease (56). Additionally, in the setting of severe immunocompromised patients, such as individuals with AIDS, $H$. capsulatum strains previously not considered virulent have been able to cause fatal disease $(23,148)$. 


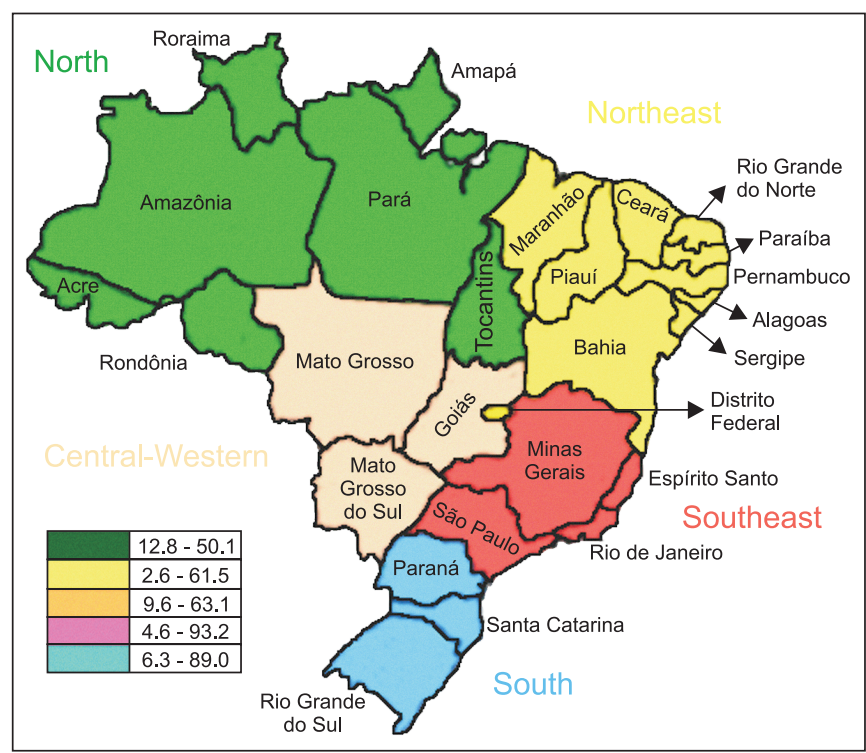

Figure 3. Distribution of histoplasmosis within Brazil as indicated by histoplasmin skin test positivity.

Importantly, infection with $H$. capsulatum usually is asymptomatic. In immunologically normal hosts in endemic areas, $95-99 \%$ of the primary infections are not recognized or detected and these asymptomatic cases might also be identified by serologic screening as part of pre-transplant evaluation or epidemiological investigation $(56,70,115)$. Symptomatic pulmonary histoplasmosis is most often a subacute, resulting from low-inoculum infection, with a mild flu-like illness characterized by a dry cough, fever and fatigue that occurs several weeks after exposure, and the radiographs usually show enlarged hilar or mediastinal lymphnodes and patchy infiltrates, but may be normal (141). Acute histoplasmosis results from a high-inoculum, the primary focus is generally pulmonary and such individuals have diverse, nonspecific symptoms, with severity of symptoms correlating with the magnitude of exposure $(85,108,126,153)$. The disseminated form is defined by the presence of an extrapulmonary focus and normally is a progressive illness occurring more frequently in immunocompromised individuals, such as patients who are receiving corticosteroids, cytotoxic therapy, and immunosuppressive agents or individuals with HIV infection $(55,111,118,135)$. Commonly seen is chronic histoplasmosis, which happens in the setting of preexisting abnormal lung architecture. This occurs most often in the presence of emphysema, where there is a local production of liquid material rich in fungal particles responsible for the chronicity of the disease (54). Mediastinal fibrosis is the least common, but the most severe, late complication of histoplasmosis. It should be differentiated from the many other less-severe mediastinal complications of histoplasmosis, and from other causes of mediastinal fibrosis. Posthistoplasmosis mediastinal fibrosis is characterized by invasive, calcified fibrosis centered on lymph nodes, which, by definition, occludes major vessels or airways. In general, the diagnosis is suggested by a hilar or mediastinal mass, which is seen in thorax radiography, because $40 \%$ of patients are asymptomatic $(96,152)$.

Although the clinical manifestations of histoplasmosis are well described, the diagnosis of histoplasmosis cannot be achieved on the basis of clinical information alone, since there is significant overlap of histoplasmosis with other diseases. For instance, mild acute histoplasmosis is similar to diverse viral respiratory tract infections. Pulmonary manifestations of more aggressive disease with pulmonary infiltrates and hilar lymphadenopathy overlap with infections by other dimorphic fungi or Mycobacterium tuberculosis. The definitive diagnosis requires the isolation of the $H$. capsulatum on specific culture media or the visualization of the yeast form in direct examination of clinical specimens using specific fungal staining techniques. However, these procedures are time consuming, usually taking a minimum of 15 days, and lack sensitivity. Furthermore $H$. capsulatum structures visualized microscopically can be confused with structures from other fungal pathogens. Also, depending on the material processed for these applications, some contaminants can out grow $H$. capsulatum, complicating the diagnosis.

Given these difficulties, other techniques have been developed to supplement culture and microscopic examination that incorporate clinical information and serology. Such laboratory tests have the benefit of a rapid turn around time and reasonable specificity and sensitivity. Detection of antibodies and antigens provides information indicative of current disease that helps in the management of the infection. Detection of precipitins by immunodiffusion to the two most important diagnostic antigens from $\mathrm{H}$. capsulatum, the $\mathrm{H}$ and $\mathrm{M}$ antigen, is one of the most widely available techniques for diagnosis, but the assay has a specificity of 70 to $100 \%$. Complement fixation tests for histoplasmosis have a sensitivity range of $70-90 \%$, but are less specific than immunodifusion (70 - 80\%) (Table 2). Antigen detection methods are also used, especially when the antibody detection is unlikely. This most often occurs in immunocompromised patients with disseminated infection who often fail to manifest an immune response. However, antigen detection assays are not universally available.

The choice of each test to be applied for diagnosis depends mainly on the clinical manifestation and host factors (89). Although attempt to culture the organism should always be pursued, culture based methods are most effective when the fungal burden is high, for instance, in some patients with chronic or disseminated forms of histoplasmosis. Culture is insensitive in sub-acute and acute histoplasmosis. Non-culture based 
Table 2. Sensitivity of laboratory tests for diagnosis of histoplasmosis.

\begin{tabular}{lccccc}
\hline \multicolumn{1}{c}{ Tests } & Self-limited $^{\mathrm{a}}$ & Acute or subacute & Chronic pulmonary & Disseminated $^{\mathrm{b}}$ & Mediastinal $^{\text {(n) }}$ \\
\hline Antigen detection & 39 & $25-75$ & $15-21$ & 92 & 0 \\
Fungal stain & 9 & 10 & $17-40$ & 43 & $<25$ \\
(Microscopy-Histopathology) & 15 & 15 & $50-85$ & 85 & $<25$ \\
Culture & 98 & 95 & 100 & 71 & 67 \\
Serology & $\mathrm{NE}$ & $\mathrm{NE}$ & $\mathrm{NE}$ & $69-100$ & $\mathrm{NE}$ \\
Molecular diagnosis & &
\end{tabular}

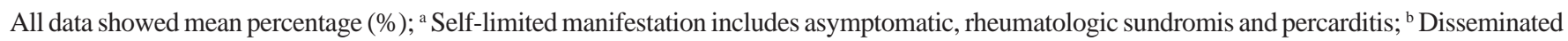
includes non-AIDS and AIDS patients (opportunistic infection); Considered the minimum and maximum sensitivity for he set of test available. Adapted from $(76,141,151)$.

methods are used in conjunction with culture to improve our ability to diagnosis $H$. capsulatum infection and can also guide therapy for histoplasmosis. Recently, some molecular biology techniques have been developed that may further improves the diagnosis of histoplasmosis, particularly for the detection of disease in an early stage and to improve the specificity of the diagnosis.

\section{Microscopy}

H. capsulatum is mycelial at $25^{\circ} \mathrm{C}$ where it grows with hyaline hyphae that have tuberculated macroconidia and smooth-walled spherical, pyriform or cigar shaped microconidia ranging in size from $2 \mu \mathrm{m}$ to $6 \mu \mathrm{m}$ in diameter $(9,36,48,104)$ (Fig. 1a). At $37^{\circ} \mathrm{C}$, yeast forms predominate that are generally ovoid thick-walled cells (Fig. 1b).

Histopathologic examinations of bone marrow aspirate or biopsy material, bronchoalveolar lavage fluid or biopsy material from lung, sputum, urine or skin lesions are frequently analyzed for the diagnosis of histoplasmosis $(5,7,24,100,101,140)$. Peripheral blood may show intracellular organisms in white blood cells in up to one half of the patients with the disseminated form of disease (55). However, bone marrow biopsy for histopathology may be the most rapid method of establishing a definitive diagnosis of invasive infection (109).

Skin scrapings, exudates and body fluids should be examined using $10 \% \mathrm{KOH}$ and Parker ink or calcofluor white mounts. Tissue sections should be stained using PAS (Periodic Acid Schiff) digest, Grocott's methenamine silver (GMS) or Gram stain $(39,128)$. Histopathology is especially useful and is one of the most important ways of alerting the laboratory that they may be dealing with a potential pathogen (76). However, these diagnostic methods lack sensitivity since they facilitate diagnosis primarily in patients with chronic, acute disseminate infection or severe pulmonary infection $(4,45,78)$.

The structure of the $H$. capsulatum yeasts is very similar to other pathogens and these characteristics can led to a mistake during the identification for diagnosis purposes (98). The misidentification occurs principally with Candida glabrata, Penicillium marneffei, Pneumocystis (carinii) jeroveci, Toxoplasma gondii, Leishmania donovani and Cryptococcus neoformans. Hence, it is extremely important to be familiar with the morphology of these pathogens and the staining characteristics of the yeast by different methods.

\section{Culture}

Definitive diagnosis is still based on the isolation and identification of $H$. capsulatum from clinical and biological specimens. Isolation of the fungus can be achieved on special media, such as Sabouraud agar, following incubation at $25^{\circ} \mathrm{C}$ for 6 to 12 weeks. Under these conditions, the fungal colonies are initially smooth, but become filamentous, cottony, and brownish with the age. Microscopically, they are composed of hyaline septated hyphaes with micro and macroconidias in various developmental stages. The conversion from the mold phase to the yeast phase is necessary for accurate diagnosis of H. capsulatum. Conversion is achieved using enriched media such as blood agar or Brain-heart infusion agar (BHI) with cystein incubated at $35-37^{\circ} \mathrm{C}$. After conversion, smooth white to brown colonies can be observed that are yeast by microscopic examination. However, $H$. capsulatum does not convert easily depending on special nutrient requirement, temperature conditions and additionally on the physiologic characteristics of the strains (38).

Detection of $H$. capsulatum is also possible from blood samples of patients with the chronic and the disseminated form. Some methodologies for improving the recovery of $H$. capsulatum in histoplasmosis patients with fungemia have been described. Lysis-centrifugation has been shown to be more effective than conventional biphasic blood systems $(102,116)$. However, the newer BACTEC type machines are highly efficient and provide a statistically significant increase compared to lysis-centrifugation for overall recovery of isolates and bloodstream infections, including most individual organism categories (49). 


\section{Non-culture based diagnosis of histoplasmosis}

Positive cultures provide the strongest evidence for histoplasmosis, but culture diagnosis has significant limitations. In particular, most patients with an asymptomatic or a mild form have negative cultures (Table 2). Non-culture methods have been developed to improve the rate and speed of diagnosis. These tests include antibody and antigen detection as well as newer techniques that have been developed in molecular diagnosis for the improved identification of $H$. capsulatum in clinical specimens. Any of the results from the described tests can provide a presumptive diagnosis of histoplasmosis and require clinical correlation for the correct evaluation and determination of the final diagnosis.

\section{Antibody detection}

Worldwide, antibody detection methods are the major tools currently in use for the non-culture diagnosis of histoplasmosis given their general availability and rapid turn around time $(22,28,139)$. The two routine methodologies are complement fixation and immunodiffusion, because of convenience, availability, and accuracy of these assays. However, these methods should not be used in patients with the disseminated form of histoplasmosis in view of the fact that there is an increase in false-negative results. Furthermore, serologic cross-reactions to Histoplasma-like antigens occur in patients infected with other common fungal pathogens. This most frequently occurs in the setting of blastomycosis, coccidioidomycosis, paracoccidioidomycosis, and aspergillosis, but also happens in patients with candidiasis and cryptococcosis $(103,137)$.

In histoplasmosis, serologic diagnosis focuses on the identification of anti-H and anti- $\mathrm{M}$ antibodies. These antibodies can be detected using histoplasmin (HMIN). HMIN is the antigenic extract obtained from H. capsulatum mycelial culture. The cells are removed by centrifugation at $1,050 \mathrm{xg}$ for $10 \mathrm{~min}$ and the supernatant is filtered through a $0.45 \mu \mathrm{m}$ membrane, concentrated and dialyzed against phosphatebuffered saline (PBS) $(15,69,105,129,154)$. The main components of HMIN to which antibody responses occur are the $\mathrm{C}, \mathrm{M}$, and $\mathrm{H}$ antigens. The $\mathrm{C}$ antigen is a carbohydrate (galactomannan) that is largely responsible for the cross-reactions observed with other fungal species (6). The $\mathrm{M}$ antigen is a catalase $(65,158)$ and the $\mathrm{H}$ antigen is a $\beta$-glucosidase $(25)$. Due to their higher specificity to $H$. capsulatum, antibodies against the $\mathrm{M}$ and $\mathrm{H}$ antigen are particularly useful in diagnosis $(59,71,95)$.

The immunodiffusion (ID) test qualitatively measures precipitating antibodies ( $\mathrm{H}$ and $\mathrm{M}$ precipitin lines or bands). Largely due to its simplicity, reliability, and potential cost effectiveness, ID testing has become increasingly popular among many laboratories. ID is highly specific for the detection of anti-M and anti-H antibodies $(46,74,80,121,122)$, but shows low sensitivity (Table 3), principally in acute manifestation of the disease. In general, ID is useful for detecting antibodies 4-6 weeks after infection. While the ID test is more specific for histoplasmosis (i.e., a person who is not infected with $H$. capsulatum is unlikely to have a positive test result) than the complement-fixation test, it is less sensitive (i.e., a person who is acutely infected can have a negative test result) (Table $3)$. The $\mathrm{H}$ band appears after the $\mathrm{M}$ band and can be found in sera from patients during acute and/or progressive disease. However, this band is present in only $7 \%$ of serum from patient with acute infection (140). Antibodies to the $\mathrm{H}$ antigen may be detected 1-2 years after the resolution of the disease, but antibodies to the $\mathrm{H}$ antigen usually disappear more quickly than the anti-M antibodies (22). The $\mathrm{H}$ precipitin rarely is detected after HMIN skin testing. The M band is more frequently detected than the $\mathrm{H}$ precipitin and appears soon after infection and can indicate prior infection, acute disease or a chronic progressive disease. The $\mathrm{M}$ precipitin reaction can persist for up to 3 years after disease resolution and can also be stimulated after skin testing with histoplasmin in people who have never had contact with $H$. capsulatum or infection $(78,83)$. The presence of both the $\mathrm{H}$ and $\mathrm{M}$ precipitins is considered to be conclusive for the diagnosis of histoplasmosis, though the status of disease requires clinical assessment of the patient.

Another common assay for antibody detection in histoplasmosis is the complement-fixation (CF) test $(57,79)$. This procedure measures antibodies to either the intact yeast form $(17,58)$ or mycelial (HMIN) antigen $(67,106,130)$. CF is more

Table 3. Serological parameters of the antibody detection techniques.

\begin{tabular}{lccl}
\hline Serological method & Sensitivity $(\%)$ & Specificity $(\%)$ & References \\
\hline Immunodifusion & $70-100$ & 100 & \\
Complement Fixation & & & \\
$\quad$ Yeast phase antigen & 94.3 & $70-80$ & \\
Mycelial phase antigen & 72.8 & & \\
Latex Agglutination & $65-97$ & $\sim 39$ & \\
ELISA & $91-100$ & $66-86$ & Torres et al. \\
& NA & $75-97$ & Raman et al. \\
& NA & $76-90$ & Zimmerman et al. \\
& 96 & 92 & Guimarães et al. \\
Western blot & & 78 & Pizzini et al. \\
p-HMIN & $45-100$ & 100 & \\
pt-HMIN & $90-100$ & & \\
\hline
\end{tabular}

Adapted from $(61,90,107,123,133,136)$;

NA - Not analyzed. 
sensitive than the immunodiffusion test but less specific (Table $3)(8,79)$. It is notable that inter-laboratory variation in titers detected can be influenced by the strain of $H$. capsulatum used for antigen preparation $(67,73,90)$. A drawback of $H$. capsulatum $\mathrm{CF}$ assay is that it can detect cross-reactive antibodies in sera from patients with other mycosis such as blastomycosis, candidiasis, coccidioidomycosis and paracoccidioidomycosis (137). Another problem with $\mathrm{CF}$ is that negative results can occur in culture-proven fungal disease, because of the blocking effect of rheumatoid factor and cold agglutinins that may develop during histoplasmosis (75). Complement-fixing antibodies may appear 3 to 6 weeks (sometimes as early as 2 weeks) following infection by $H$. capsulatum in $95 \%$ of the patients with histoplasmosis, and repeated tests will give positive results for months (136). Titers between 1:8 and 1:16 are considered weakly positive and are observed in almost one quarter of patients (73). However, these titers may represent past infection and can also be detected in the serum of healthy persons from regions where histoplasmosis is endemic. A high titer (1:32 or greater) or a fourfold increase in titer over time is indicative of active histoplasmosis (79). Antibody titers will gradually decline and eventually disappear months to years following recovery in the absence of re-exposure, but persist for years in individuals with recurrent exposures.

Latex agglutination tests have been developed in an attempt to eliminate cross reactions and increase sensitivity $(88,119)$. There is a commercial Latex agglutination assay for histoplasmosis, but false positives results are found in patients with tuberculosis (30). Some authors have reported that this test is more sensitive than the CF using HMIN as antigen, where antibodies were detected in $97 \%$ of serum samples from patients with acute histoplasmosis, $96 \%$ in chronic pulmonary and $64 \%$ in disseminated histoplasmosis, while the CF test detected 38\% in acute, $73 \%$ in chronic pulmonary and $45 \%$ in disseminated histoplasmosis (50). Generally sera from patients with AIDS lack detectable antibodies by either CF or agglutination tests (120). A hemagglutination test was also developed for detection of antibody to $H$. capsulatum. This test was sensitive enough to detect antibodies in sera which were negative by $\mathrm{CF}$ and/or ID, but it failed to discriminate reliably between antibodies to $H$. capsulatum and B. dermatitidis (82). A comparison of the tests is shown in the Table 3.

Antibodies to $H$. capsulatum can also be detected by immunoenzimatic assays such as Western blot and ELISA. Western blot technology has been used successfully in order to diagnose histoplasmosis and evaluate epidemiologically the distribution of the disease. Using Western blot, four different Histoplasma antigens of 91, 83, 70 and $38 \mathrm{kDa}$ have been identified that react with sera from patients with histoplasmosis (133). Using purified and deglycosylated histoplasmin (ptHMIN) (131,154-156), the sensitivity of the Western blot can be significantly improved. In one study, the sensitivity of a Western blot using the native glycosylated antigen was $45 \%$ with acutephase serum samples and $100 \%$ for convalescent-phase specimens, while sensitivity increased to $90 \%$ for the acutephase specimens when using the deglycosylated antigen (107).

Several enzyme-linked immunosorbent assays (ELISA) protocols have been described for antibody detection using diverse antigenic preparations (113). An indirect sandwich ELISA for the detection of antibodies to $H$. capsulatum ribosomes and histoplasmin has been developed where antiribosomal antibodies were detected in $97 \%$ of histoplasmosis patients, but antibodies to histoplasmin were detected in only $75 \%$ of samples (110). An ELISA using a yeast cell extract showed a sensitivity of $86 \%$ in acute pulmonary histoplasmosis and a specificity of $91 \%$ using anti-human IgG, whereas with antihuman IgM the sensitivity was $66 \%$ and the specificity $100 \%$ (133). One ELISA using ferrous metal beads for determination of immunoglobulins $\mathrm{G}$ and $\mathrm{M}$ to $H$. capsulatum detected histoplasmal antibody in $90 \%$ of the specimens that were negative by CF, $76 \%$ that were negative by ID, and $100 \%$ that were negative by both CF and ID, when limited to specimens collected within 4 months of the onset of histoplasmosis symptoms (160). An indirect ELISA was developed and evaluated as a method for detecting antibodies against glycosylated and deglycosylated histoplasmin (HMIN), and the sensitivity obtained was $92 \%$ and the specificity, $96 \%$ and is a useful adjunct to existing methods of diagnosis that could be applied even in situations where laboratory facilities are relatively limited (61). This last methodology has been evaluated and validated as a specific and sensitive immunoassay for the detection of the antibodies in sera from patients with all the clinical manifestations of histoplasmosis (62).

\section{Antigen detection}

Antigen detection tests may be more effective than antibody testing for diagnosing of histoplasmosis (84). During infection with $H$. capsulatum, antigen can be released by the fungal cells and detected in body fluids such as serum (blood), pleural fluid, bronchoalveolar lavage fluid, cerebrospinal fluid and urine $(145,149,150)$. Antigen detection can be particularly useful in acute disease, especially in individuals also infected with HIV, who frequently have the disseminated form of histoplasmosis without detectable antibodies to the fungus (146-148).

The first described methods for antigen detection used fluorescent antibodies for the screening and identification of H. capsulatum in sputum $(77,93)$ and in immunohistochemical tests (72). A radioimmunoassay for the detection of $H$. capsulatum antigen in urine and serum specimens based on the detection of a polysaccharide antigen from $\mathrm{H}$. capsulatum (HPA) using polyclonal rabbit serum has been particularly effective, especially in patients with disseminated histoplasmosis, with the original assay detecting antigens in urine of 20 samples of the 22 tested (91\%) and in blood, 11 
samples of the 22 tested (149). Ongoing efforts to improve this method have resulted in increased levels of detection, with high levels of HPA detected in the urine of $95 \%$ and the serum of $86 \%$ AIDS/disseminated histoplasmosis patients $(142,144)$. In general, patients with disseminated histoplasmosis have high levels of Histoplasma antigenuria, and the determination of titers by radioimmunoassay, besides being important for diagnosis, is useful for monitoring the effect of treatment (44) and management of histoplasmosis. Usually diminution in titer of detectable antigens is directly correlated with improvement on the patient clinical condition $(51,144)$. False-positive Histoplasma antigen detection tests can occur in patients with blastomycosis or paracoccidioidomycosis (47).

Two enzyme-linked immunosorbent assays (ELISA) for detection of HPA have been described and compared with the solid-phase radioimmunoassay (Table 4). The ELISA has some advantages over an RIA because it does not expose the workers to radioactivity and the conjugate (either Alkaline phosphatase or Horseradish peroxidase) seems to be more stable than the radioactive ${ }^{125} \mathrm{I}$ labeled antibodies. However, the AP-ELISA and HRP-ELISA appear less sensitive than RIA and could not detect antibodies in specimens containing lower levels of HPA, giving false negative results (161). A similar antigen test has been adapted to an enzyme immunoassay format and the results obtained were similar to the RIA assays (34). However, urine sample studies have shown that cross-reactivity occurs to Paracoccidioides brasiliensis, Blastomyces dermatitidis, Coccidioides immitis, and Penicillium marneffei (138). Falsepositive antigenemia can also occur in patients who received rabbit antithymocyte globulin, since the infused antibodies recognize the polyclonal serum used (143). Nevertheless, these tests provide rapid and accurate diagnosis in patients with acute pulmonary or disseminated infection and both urine and serum should be tested to provide the highest sensitivity for diagnosis. In the case of suspected meningitis, the CSF should be tested. Bronchoalveolar lavage fluid can be tested in the setting of pulmonary histoplasmosis, while the usefulness of urine and serum is unknown for this purpose (144). In chronic disease, the antigen detection may be negative due to the low fungal burden and failure to detect antigens in serum, being the serological tests for anti-Histoplasma antibodies positive in most of cases (76).

An inhibition ELISA has also been developed for the detection of a $70 \mathrm{kDa}$ protein using a speciesspecific murine monoclonal antibody (52). Overall, this test detected antigen in $71.4 \%$ of the histoplasmosis serum samples tested. The sensitivity varied among 57.1 to $88.9 \%$ according to clinical form of histoplasmosis. The specificity was $85.4 \%$ when serum samples of other mycosis were used. This methodology is useful for the follow-up of histoplasmosis patients during treatment and the monitoring of disease in non-AIDS patients with the acute or disseminated form of the disease (51).

Comparison between the sandwich-ELISA and the inhibition ELISA showed similar results when sera from histoplasmosis patients were evaluated, but the sandwich-ELISA was more effective when urine from the same patients were analyzed (Table 4).

\section{Skin testing}

This method evaluates the reactivity of the patients with histoplasmosis when challenged intradermally with fungal proteins (HMIN) $(35,122)$. Some studies have suggested that this methodology has an application on diagnosis of primary, symptomatic or asymptomatic infections caused by $H$. capsulatum in immunocompetent individuals $(37,132)$. However, HMIN skin testing is currently largely used for research rather than for clinical purposes. Testing with HMIN is particularly useful in epidemiological studies in non-endemic geographic regions in individuals who occasionally visit endemic areas or during epidemics. Epidemiological investigations in Brazil have demonstrated the utility of this assay $(27,117)$. Skin test was most recently reported to be useful in an outbreak investigation in a University in Texas, correlated to construction projects on the campus that involved previously wooded land and was adjacent to a large bird sanctuary (92).

\section{Exoantigens}

Exoantigens are valuable for the immunoidentification of fungal pathogens and for resolving taxonomic problems. Most fungi produce unique antigens that allow specific identification. Exoantigens are soluble immunogenic macromolecules produced by fungi early in their development (81). The conventional exoantigen method using immunodiffusion test for detection of

Table 4. Antigen detection techniques and their parameters.

\begin{tabular}{lcccc}
\hline \multirow{2}{*}{ Antigen detection test } & \multicolumn{3}{c}{ Sensitivity (\%) $^{\text {Specificity }}$} \\
\cline { 3 - 4 } & & 95 & 48 & 96 \\
Disseminated $^{\mathrm{a}}$ & $\begin{array}{c}\text { Non- } \\
\text { Disseminated }^{\mathrm{b}}\end{array}$ & $(\%)$ \\
\hline RIA & & 25 & 92 \\
Sandwich ELISA & AP $^{\mathrm{c}}$ & 89 & 25 & 96 \\
& HRP $^{\mathrm{d}}$ & 89 & 16 & 85 \\
\hline \multirow{2}{*}{ Inhibition-ELISA } & 68 & 75 & \\
\hline
\end{tabular}

aDisseminated includes disseminated non AIDS and opportunistic infection; ${ }^{\mathrm{b}}$ Non disseminated includes acute, chronic, mediastinal and self-limited infections; ${ }^{\mathrm{c}}$ Alkaline-Phosphatase;

${ }^{\mathrm{d}}$ Horseradish peroxidase; Adapted from $(34,52,149)$. 
$\mathrm{H}$ and $\mathrm{M}$ proteins has been a valuable tool for immunoidentification of the mycelial form of atypical $H$. capsulatum and discriminating this fungus from many saprophytic fungi in the genera Arthroderma, Chrysosporium, Corynascus, Renispora, and Sepedonium that have mycelial forms that grossly and microscopically resemble those of $H$. capsulatum. However this method is time-consuming and false negative results can occur. Considering that immunoenzyme assays are more sensitive than precipitation techniques, and that nucleic acids-based methodologies show higher specificity than immunological tests, alternative methods for rapid identification of $H$. capsulatum have been developed and evaluated for us. Dot-blot and immunoblotting assays have been compared with traditional tests to detect soluble species-specific macromolecule produced by $H$. capsulatum in culture $(31,112)$. Duplicates of 5 to 7-days-old cultures of $H$. capsulatum grown in BHI broth were used as source of exoantigens. After $24 \mathrm{~h}$ of thimerosal sterilization, the exoantigens were obtained from the supernatant by concentration, and probed by dot-blot and immunoblot against homologous rabbit anti-H. capsulatum serum. These exoantigens were also tested by ID. All the isolates studied were correctly identified as $H$. capsulatum by these alternative methods. The immunoassays showed higher sensitivity (12/12 - 100\%) than ID (4/12 - 33\%) (112).

\section{Molecular based methods}

As described, H. capsulatum colonies grow slowly and the differentiation form other dimorphic or saprophytic fungi having similar colony or microscopic morphology is challenging. In order to confirm the diagnosis, tests for the production of exoantigens and the conversion to the yeast phase should be done, which takes at least 3 to 4 weeks. Methods for the identification of fungal isolates such as species-specifics DNA, can decrease this time consuming step, while maintaining or improving the specificity, accuracy and sensitivity (68). The use of chemiluminescence-labeled DNA probes for the detection of specific sequences of rRNA has been able to detect and confirm all of the $41 \mathrm{H}$. capsulatum clinical isolates tested (18). Also, these probes could detect $H$. capsulatum directly on excised tissues, such as excised heart valves from patients with Histoplasma endocarditis (18).

Polymerase Chain Reaction (PCR) diagnosis based on the amplification of fungal gene sequences is a powerful tool for identifying invasive mycoses. A new nested PCR has been tested in murine models of histoplasmosis and compared to quantitative cultures (12). The primers sequence used in this method were based on the small-subunit (18S) rRNA gene of $H$. capsulatum. The nested PCR could detect $H$. capsulatum DNA in tissue and blood samples from infected animals, but not specifically because preliminary data showed that the assay could also detect DNA of Blastomyces dermatitidis and Paracoccidioides brasiliensis. This method, when compared with other staining methods for $H$. capsulatum detection, was the most sensitive for detecting the fungus in the spleens of experimentally infected mice (10) and all the samples used were paraffin-embedded to reflect routine procedures in histopathology and also provides the possibility of repetitive examinations. Detection of fungal DNA in human formalin fixed and paraffin-embedded tissue has been described using nested PCR assays. One method, using specific primers targeting the gene coding for a specific $100 \mathrm{kDa}$ protein, had no false-positive results and detected fungal DNA in all the histopathologically positive biopsy specimens (11). A second assay using primers for the 18S rRNA gene, amplified DNA in histopatologically negative samples (11). Because PCR products detected could potentially be generated by nonspecific amplification of DNA from nonpathogenic fungal species, the products had to be confirmed by sequencing. The detection of $H$. capsulatum DNA in choroidal lesions in histopathological sections from a patient with a chronic ocular histoplasmosis syndrome was also accomplished using another set of primers to the rRNA gene (127). Using the sequence of the $\mathrm{H}$ antigen gene, primers were selected and a semi-nested PCR developed. Comparison of this method using biopsy, blood and skin scraping with MayGrunwald-Giemsa staining and culture revealed similar results except that the PCR method detected H. capsulatum DNA in two culture negative blood samples (14). The result of these studies is that PCR can be a useful additional tool for diagnosis of $H$. capsulatum, especially in non-endemic regions, to complement antigen detection and serological methods. Additionally, the molecular methods are safer, limiting the possibility of laboratory infection, due to degradation of the pathogen by the genetic material extraction (114).

Recently, a PCR was developed for rapid identification of $H$. capsulatum isolates in culture (60). In this method, two oligonucleotide primers pairs, Msp1F-Msp1R and Msp2FMsp2R, were designed based on the sequences of the $M$ gene (158). With this PCR assay using respectively the primers cited, 111 and 249 bases pair products were amplified successfully from $31 \mathrm{H}$. capsulatum strains and the method showed $100 \%$ sensitivity. Studies are in progress to analyze the specificity of this PCR assay. Therefore, this alternative methodology appears to offer the potential for improving the current methods for identification of this pathogenic mould, mainly when applied in atypical isolates. Comparison of all the methods described here is seen on the Table 5 .

\section{Future diagnosis of histoplasmosis}

The methods described for the diagnosis of histoplasmosis each have their strength, weakness and require critical analysis by microbiologists and clinicians. The immunological status of the patient and manifestation of disease influence the efficacy of the diagnostic test. Not all tests described are universally reading available, which complicates the ability to diagnose e 
Table 5. Specificity and sensitivity of DNA based techniques for the diagnosis of histoplasmosis on clinical specimens.

\begin{tabular}{lcc}
\hline Molecular methods & Sensitivity (\%) & Specificity (\%) \\
\hline Accuprobe & 100 & 100 \\
Nested-PCR & & \\
$\quad$ 100KDa protein gene & 69 & 100 \\
18S rRNA gene & 90 & 62 \\
Semi-Nested PCR & & \\
$\quad$ H antigen gene & 100 & 100 \\
\hline
\end{tabular}

Adapted from (10,11,14,18,68,114).

treat individuals with histoplasmosis. Ongoing efforts to improve or develop diagnostic tests will facilitate our diagnostic capabilities. However, such assays will require validation in populations from various regions in the world prior to general applications in routine diagnosis.

Due to the high number of histoplasmosis cases associated with AIDS, efforts have been made to develop new antigens detection techniques with improved sensitivity and specificity. Monoclonal antibodies are highly specific reagents, recognizing a single antigenic determinant $(63,64)$. Characterization of these reagents could provide information about their specificity for a unique fungal antigen. The use of such reagents for diagnosis could improve the parameters of the antigen and antibody detection techniques.

Use of recombinant $H$. capsulatum proteins may result in an improved assay because defined antigens could avoid the use of complex, poorly characterized and non-standardized antigenic mixtures and decrease the cross-reactions existing in the antibody and antigen detection techniques described $(25,158)$.

Molecular diagnosis has been growing in importance, due to the facility of its application and efficiency. The need for a rapid and accurate method for the detection of fungal pathogens has become imperative as the incidence of fungal infections has increased dramatically. Also, the quickness of the diagnosis regarding an early detection is important to determine the disease before the clinical symptoms are present, and then evaluate the treatment depending on the clinical form of the patient $(76,141)$. PCR using more specific primers could give us earlier results of H. capsulatum infection, in clinical samples as biopsies, as well blood, sputum and CSF.

Also on the horizon is a high-throughput screen methodology described for the detection of fungal pathogen sequences (26). With rapid advances in molecular biology, combined with fungal sequence database and the public accessibility of microbial sequence data, the Luminex technology could provide a rapid and simple assay with a high-throughput capability to identify $H$. capsulatum in clinical samples. This technology uses a microsphere-based hybridization assay uses PCR-biotinylated amplicon target DNA, which is inoculated into a microsphere bead mixture containing species-specific probes of interest. Design of probes and validation of this methodology should be done, and evaluated for a more accurate diagnosis of histoplasmosis.

\section{RESUMO}

\section{Diagnóstico Laboratorial da Histoplasmose}

As micoses endêmicas podem ser um desafio com relação ao diagnóstico e a interpretação acurada dos dados laboratoriais é importante para garantir um tratamento mais apropriado para os pacientes. Embora o diagnóstico definitivo da histoplasmose (HP), uma das micoses endêmicas no mundo, seja determinado pelo exame direto com a observação de micro e macroconídeos do Histoplasma capsulatum (H. capsulatum), evidências sorológicas da infecção fúngica se torna importante uma vez que o isolamento dos agentes etiológicos é um procedimento demorado e com baixa sensibilidade. Uma variedade de imunoensaios tem sido usada para detectar anticorpos específicos contra o $H$. capsulatum. A técnica mais aplicada para a detecção de anticorpos é a imunodifusão, apresentando uma sensibilidade entre 70 a $100 \%$ e especificidade de dependendo da forma clínica. A fixação de complemento (CF), uma metodologia que foi extensivamente usada no passado, apresenta uma menor especificidade (60 to 90\%). A detecção de antígenos fúngicos pelos imunoensaios é valiosa para indivíduos imunocomprometidos onde cada ensaio garante valores preditivos positivos variando de 96-98\%. A maioria dos testes atual ainda utiliza antígenos complexos não-purificados obtidos de parede celular fúngica ou filtrados de cultura. Contudo, importância tem sido dada a imunoensaios clínicos utilizando antígenos altamente purificados e caracterizados, incluindo antígenos recombinantes. Neste manuscrito, nós revisamos as ferramentas atuais utilizadas no diagnóstico, como fixação de complemento e imunodifusão, sumarizando o desenvolvimento de novas tecnologias, reagentes e métodos, e discutiremos aqui os seus méritos relativos e desvantagens no imunodiagnóstico desta micose.

Palavras-chave: testes diagnósticos, métodos baseados em cultura, métodos moleculares e sorologia

\section{REFERENCES}

1. Ajello, L. Coccidioidomycosis and histoplasmosis. A review of their epidemiology and geographical distribution. Mycopathol. Mycol. Appl., 45(3), 221-230, 1971.

2. Allendoerfer, R.; Biovin, G.P.; Deepe Jr., G.S. Modulation of immune responses in murine pulmonary histoplasmosis. J. Infect. Dis., 175(4), 905-914, 1997. 
3. Alteras, I. First Romanian isolation of Histoplasma capsulatum from the soil. Dermatol. Int., 5(2), 69-71, 1966.

4. Arechavala, A.I.; Robles, A.M.; Negroni, R.; Bianchi, M.H.; Taborda, A. [Value of direct and indirect diagnostic methods in systemic mycoses associated with AIDS]. Rev. Inst. Med. Trop., São Paulo, 35(2), 163-169, 1993.

5. Atkinson, G.W.; Randall, E. The diagnosis of fungal infections of the respiratory tract. Ann. Clin. Lab. Sci., 3(3), 194-200, 1973.

6. Azuma, I.; Kanetsuna, F.; Tanaka, Y.; Yamamura, Y.; Carbonell, L.M. Chemical and immunological properties of galactomannans obtained from Histoplasma duboisii, Histoplasma capsulatum, Paracoccidioides brasiliensis and Blasomyces dermatitidis. Mycopathol. Mycol. Appl., 54(1), 111-125, 1974.

7. Baughman, R.P.; Kim, C.K.; Bullock, W.E. Comparative diagnostic efficacy of bronchoalveolar lavage, transbronchial biopsy, and openlung biopsy in experimental pulmonary histoplasmosis. J. Infect. Dis., 153(2), 376-377, 1986.

8. Bauman, D.S.; Smith, C.D. Comparison of immunodiffusion and complement fixation tests in the diagnosis of histoplasmosis. $J$. Clin. Microbiol., 2(2), 77-80, 1976.

9. Berliner, M.D. Histoplasma capsulatum: vital staining for the differentiation of the albino and brown phenotypes in vitro. Sabouraudia, 11(3), 271-273, 1973.

10. Bialek, R.; Ernst, F.; Dietz, K.; Najvar, L.K.; Knobloch, J.; Graybill, J.R.; Schaumburg-Lever, G. Comparison of staining methods and a nested PCR assay to detect Histoplasma capsulatum in tissue sections. Am. J. Clin. Pathol., 117(4), 597-603, 2002.

11. Bialek, R.; Feucht, A.; Aepinus, C.; Just-Nubling, G.; Robertson, V.J.; Knobloch, J.; Hohle, R. Evaluation of two nested PCR assays for detection of Histoplasma capsulatum DNA in human tissue. J. Clin. Microbiol., 40(5), 1644-1647, 2002.

12. Bialek, R.; Fischer, J.; Feucht, A.; Najvar, L.K.; Dietz, K.; Knobloch, J.; Graybill, J.R. Diagnosis and monitoring of murine histoplasmosis by a nested PCR assay. J. Clin. Microbiol., 39(4), 1506-1509, 2001.

13. Borelli, D. Prevalence of systemic mycosis in Latin America. Proc. Int. Symp. Mycoses Scient. Publ., 205, 1970.

14. Bracca, A.; Tosello, M.E.; Girardini, J.E.; Amigot, S.L.; Gomez, C.; Serra, E. Molecular detection of Histoplasma capsulatum var. capsulatum in human clinical samples. J. Clin. Microbiol., 41(4), 1753-1755, 2003.

15. Bradley, G.; Pine, L.; Reeves, M.W.; Moss, C.W. Purification, composition, and serological characterization of histoplasmin-H and $\mathrm{M}$ antigens. Infect. Immun., 9(5), 870-880, 1974.

16. Bradsher, R.W. Histoplasmosis and blastomycosis. Clin. Infect. Dis., 22(Suppl. 2), S102-111, 1996.

17. Campbell, C.C. Use of yeast phase antigens in a complement fixation test for histoplasmosis. IV. Results with ground yeast phase antigens in serial specimens of serums from thirty-seven patients. Public Health Monogr., 70(39), 140-143, 1956.

18. Chemaly, R.F.; Tomford, J.W.; Hall, G.S.; Sholtis, M.; Chua, J.D.; Procop, G.W. Rapid diagnosis of Histoplasma capsulatum endocarditis using the AccuProbe on an excised valve. J. Clin. Microbiol., 39(7), 2640-2641, 2001.

19. Couto, M.A.; Liu, L.; Lehrer, R.I.; Ganz, T. Inhibition of intracellular Histoplasma capsulatum replication by murine macrophages that produce human defensin. Infect. Immun., 62(6), 2375-2378, 1994.

20. Csillag, A.; Wermer, T. [Histoplasmosis.]. Orv. Hetil., 97(35), 964967, 1956.

21. Darling, S.T. A protozoan general infection producing pseudotubercules in the lungs and focal necrosis in the liver, spleen and lymph nodes. J. Am. Med. Ass., (JAMA). 46, 1283-1285, 1906.

22. Davies, S.F. Serodiagnosis of histoplasmosis. Semin. Respir. Infect., 1(1), 9-15, 1986
23. Davies, S.F.; Khan, M.; Sarosi, G.A. Disseminated histoplasmosis in immunologically suppressed patients. Occurrence in a nonendemic area. Am. J. Med., 64(1), 94-100, 1978.

24. Davis, O.; Wolff, A.P. Pathologic diagnosis: histoplasmosis of the tonsil. Arch. Otolaryngol., 111(8), 558-560, 1985.

25. Deepe Jr, G.S.; Durose, G.G. Immunobiological activity of recombinant $\mathrm{H}$ antigen from Histoplasma capsulatum. Infect. Immun., 63(8), 3151-3157, 1995.

26. Diaz, M.R.; Fell, J.W. High-throughput detection of pathogenic yeasts of the genus trichosporon. J. Clin. Microbiol., 42(8), 3696-3706, 2004.

27. Diogenes, M.J.; Gonçalves, H.M.; Mapurunga, A.C.; Alencar, K.F.; Andrade, F.B.; Nogueira-Queiroz, J.A. Reações a histoplasmina e paracoccidioidina na Serra de Pereiro (Estado do Ceara-Brasil). Rev. Ins. Med. Trop., São Paulo, 32(2), 116-120, 1990.

28. DiSalvo, A.F. Histoplasma capsulatum serology. J. Clin. Microbiol., 24(5), 905, 1986.

29. Disalvo, A.F.; Bigler, W.J.; Ajello, L.; Johnson, J.E.; Palmer, J. Bat and soil studies for sources of histoplasmosis in Florida. Public. Health. Rep., 85(12), 1063-1069, 1970.

30. DiSalvo, A.F.; Corbett, D.S. Apparent false positive histoplasmin latex agglutination tests in patients with tuberculosis. J. Clin. Microbiol., 3(3), 306-308, 1976.

31. DiSalvo, A.F.; Sekhon, A.S.; Land, G.A.; Fleming, W.H. Evaluation of the exoantigen test for identification of Histoplasma species and Coccidioides immitis cultures. J. Clin. Microbiol., 11(3), 238-241, 1980.

32. Dodd, K.A.W.H. Case of histoplasmosis of Darling in a infant. Am. J. Trop. Med., 14, 127-137, 1934.

33. Duncan, J.T. Tropical African histoplasmosis. Trans. R. Soc. Trop. Med. Hyg., 52(5), 468-474, 1958.

34. Durkin, M.M.; Connolly, P.A.; Wheat, L.J. Comparison of radioimmunoassay and enzyme-linked immunoassay methods for detection of Histoplasma capsulatum var. capsulatum antigen. J. Clin. Microbiol., 35(9), 2252-2255, 1997.

35. Edwards, L.B.; Acquaviva, F.A.; Livesay, V.T.; Cross, F.W.; Palmer, C.E. An atlas of sensitivity to tuberculin, PPD-B, and histoplasmin in the United States. Am. Rev. Respir. Dis., 99(Suppl. 4), 1-132, 1969.

36. Edwards, M.R.; Hazen, E.L.; Edwards, G.A. The micromorphology of the tuberculate spores of Histoplasma capsulatum. Can. J. Microbiol., 6, 65-70, 1960.

37. Edwards, P.Q.; Billings, E.L. Worldwide pattern of skin sensitivity to histoplasmin. Am. J. Trop. Med. Hyg., 20(2), 288-319, 1971.

38. Eissenberg, L.G.; Goldman, W.E. Histoplasma variation and adaptive strategies for parasitism: new perspectives on histoplasmosis. Clin. Microbiol. Rev., 4, 411-21, 1991.

39. Elias Costa, M.R.; Da Silva Lacaz, C.; Kawasaki, M.; De Camargo, Z.P. Conventional versus molecular diagnostic tests. Med. Mycol., 38(Suppl. 1), 139-145, 2000.

40. Emmons, C.W. Histoplasmosis in animals. Public Health Monogr., 70(39), 272-273, 1956.

41. Emmons, C.W. Isolation of Histoplasma capsulatum from soil. Public Health Monogr., 70(39), 237-239, 1956.

42. Emmons, C.W. Histoplasmosis: animal reservoirs and other sources in nature of the pathogenic fungus Histoplasma capsulatum. Am. J. Public Health., 40, 436-440, 1950.

43. Emmons, C.W.; Klite, P.D.; Baer, G.M.; Hill, W.B., Jr. Isolation of Histoplasma capsulatum from bats in the United States. Am. J. Epidemiol., 84(1), 103-109, 1966.

44. Fojtasek, M.F.; Kleiman, M.B.; Connolly-Stringfield, P.; Blair, R.; Wheat, L.J. The Histoplasma capsulatum antigen assay in disseminated histoplasmosis in children. Pediatr. Infect. Dis. J., 13(9), 801-805, 1994.

45. Furcolow, M.L. The clinical diagnosis of histoplasmosis. Postgrad. Med., 20(4), 349-364, 1956. 
46. Furcolow, M.L.; Salvin, S.B. The precipitin test in human histoplasmosis. Public Health Monogr., 70(39), 129-131, 1956.

47. Garner, J.A.; Kernodle, D. False-positive Histoplasma antigen test in a patient with pulmonary blastomycosis. Clin. Infect. Dis., 21(4), 1054, 1995

48. Garrison, R.G.; Boyd, K.S. The fine structure of microconidial germination and vegetative cells of Histoplasma capsulatum. Ann. Microbiol., (Paris), 128(2), 135-149, 1977.

49. Gaur, A.H.; Giannini, M.A.; Flynn, P.M.; Boudreaux, J.W.; Mestemacher, M.A.; Shenep, J.L.; Hayden, R.T. Optimizing blood culture practices in pediatric immunocompromised patients: evaluation of media types and blood culture volume. Pediatr. Infect. Dis. J., 22(6), 545-552, 2003.

50. Gerber, J.D.; Riley, R.E.; Jones, R. Evaluation of a microtiter latex agglutination test for histoplasmosis. Appl. Microbiol., 24(2), 191$197,1972$.

51. Gomez, B.L.; Figueroa, J.I.; Hamilton, A.J.; Diez, S.; Rojas, M.; Tobon, A.; Restrepo, A.; Hay, R.J. Detection of the 70-kilodalton Histoplasma capsulatum antigen in serum of histoplasmosis patients: correlation between antigenemia and therapy during follow-up. $J$. Clin. Microbiol., 37(3), 675-680, 1999.

52. Gomez, B.L.; Figueroa, J.I.; Hamilton, A.J.; Ortiz, B.L.; Robledo, M.A.; Restrepo, A.; Hay, R.J. Development of a novel antigen detection test for histoplasmosis. J. Clin. Microbiol., 35(10), 26182622, 1997.

53. Goodwin Jr., R.A.; Des Prez, R.M. State of the art: histoplasmosis. Am. Rev. Respir. Dis., 117(5), 929-956, 1978.

54. Goodwin Jr., R.A.; Owens, F.T.; Snell, J.D.; Hubbard, W.W.; Buchanan, R.D.; Terry, R.T.; Des Prez, R.M. Chronic pulmonary histoplasmosis. Medicine (Baltimore), 55(6), 413-452, 1976.

55. Goodwin, Jr., R.A.; Shapiro, J.L.; Thurman, G.H.; Thurman, S.S.; Des Prez, R.M. Disseminated histoplasmosis: clinical and pathologic correlations. Medicine (Baltimore), 59(1), 1-33, 1980.

56. Goodwin, R.A.; Loyd, J.E.; Des Prez, R.M. Histoplasmosis in normal hosts. Medicine (Baltimore). 60(4), 231-266, 1981.

57. Grayston, J.T. A study of the complement fixation reaction in histoplasmosis. J. Lab. Clin. Med., 40(1), 90-101, 1952.

58. Grayston, J.T. A study of the complement fixation reaction in histoplasmosis, employing whole yeast phase cells as antigen. Public Health Monogr., 70(39), 132-139, 1956.

59. Gross, H.; Bradley, G.; Pine, L.; Gray, S.; Green, J.H.; Harrell, W.K. Evaluation of histoplasmin for the presence of $\mathrm{H}$ and $\mathrm{M}$ antigens: some difficulties encountered in the production and evaluation of a product suitable for the immunodiffusion test. J. Clin. Microbiol., $1(3), 330-334,1975$

60. Guedes, H.L.; Guimaraes, A.J.; Muniz Mde, M.; Pizzini, C.V.; Hamilton, A.J.; Peralta, J.M.; Deepe Jr., G.S.; Zancope-Oliveira, R.M. PCR assay for identification of Histoplasma capsulatum based on the nucleotide sequence of the M antigen. J. Clin. Microbiol., 41(2), 535-539, 2003.

61. Guimarães, A.J.; Pizzini, C.V.; De Matos Guedes, H.L.; Albuquerque, P.C.; Peralta, J.M.; Hamilton, A.J.; Zancope-Oliveira, R.M. ELISA for early diagnosis of histoplasmosis. J. Med. Microbiol., 53(Pt 6), 509-514, 2004.

62. Guimarães, A.J.; Pizzini, C.V.; Santoro, D.O.; Albuquerque, P.C.; Pimenta, M.A.; Peralta, J.M.; Zancopé-Oliveira, R.M. Evaluation of Enzyme Linked Immunosorbent Assay (ELISA) for Antibody Response in the Clinical Forms of Histoplasmosis. 105 ${ }^{\text {th }}$ General Meeting. Am. Soc. Microbiol., 49(F-017), 2005.

63. Hamilton, A.J.; Bartholomew, M.A.; Fenelon, L.; Figueroa, J.; Hay, R.J. Preparation of monoclonal antibodies that differentiate between Histoplasma capsulatum variant capsulatum and $H$. capsulatum variant duboisii. Trans. R. Soc. Trop. Med. Hyg., 84(3), 425-428, 1990.

64. Hamilton, A.J.; Bartholomew, M.A.; Fenelon, L.E.; Figueroa, J.; Hay, R.J. A murine monoclonal antibody exhibiting high species specificity for Histoplasma capsulatum var. capsulatum. J. Gen. Microbiol., 136(2), 331-335, 1990.

65. Hamilton, A.J.; Bartholomew, M.A.; Figueroa, J.; Fenelon, L.E.; Hay, R.J. Evidence that the M antigen of Histoplasma capsulatum var. capsulatum is a catalase which exhibits cross-reactivity with other dimorphic fungi. J. Med. Vet. Mycol., 28(6), 479-485, 1990.

66. Hay, R.J. Laboratory techniques in the investigation of fungal infections. Genitourin. Med., 68(6), 409-412, 1992.

67. Hill, G.B.; Campbell, C.C. A further evaluation of histoplasmin and yeast phase antigen of Histoplasma capsulatum in the complement fixation test. J. Lab. Clin. Med., 48(2), 255-263, 1956.

68. Huffnagle, K.E.; Gander, R.M. Evaluation of Gen-Probe's Histoplasma capsulatum and Cryptococcus neoformans AccuProbes. J. Clin. Microbiol., 31(2), 419-421, 1993.

69. Huppert, M.; Adler, J.P.; Rice, E.H.; Sun, S.H. Common antigens among systemic disease fungi analyzed by two-dimensional immunoelectrophoresis. Infect. Immun., 23(2), 479-485, 1979.

70. Isbister, J.; Elliott, M.; Nogrady, S. Histoplasmosis: an outbreak occurring among young men who visited one cave. Med. J. Aust., 2(7), 243-248, 1976.

71. Jacobson, E.S.; Straus, S.E. Serologic tests for histoplasmosis. Ann. Intern. Med., 98(4), 560-561, 1983.

72. Jensen, H.E.; Schonheyder, H.C.; Hotchi, M.; Kaufman, L. Diagnosis of systemic mycoses by specific immunohistochemical tests. Apmis., 104(4), 241-258, 1996.

73. Johnson, J.E.; Goodman, N.L. Variation in complement fixation test results with three Histoplasma capsulatum yeast phase antigens. J. Clin. Microbiol., 22(6), 1066-1067, 1985.

74. Johnson, J.E.; Jeffery, B.; Huppert, M. Evaluation of five commercially available immunodiffusion kits for detection of Coccidioides immitis and Histoplasma capsulatum antibodies. J. Clin. Microbiol., 20(3), 530-532, 1984.

75. Johnson, J.E.; Roberts, G.D. Blocking effect of rheumatoid factor and cold agglutinins on complement fixation tests for histoplasmosis J. Clin. Microbiol., 3(2), 157-160, 1976.

76. Joseph Wheat, L. Current diagnosis of histoplasmosis. Trends Microbiol., 11(10), 488-494, 2003.

77. Kaufman, L. The application of fluorescent antibody techniques for the detection and identification of mycotic disease agents. Mycopathol. Mycol. Appl., 26(2), 257-263, 1965.

78. Kaufman, L. Laboratory methods for the diagnosis and confirmation of systemic mycoses. Clin. Infect. Dis., 14(Suppl. 1), S23-9, 1992.

79. Kaufman, L.; Huppert, M.; Fava-Neto, C.; Negroni, R.; Restrepo, A. Manual of standardized serodiagnostic procedures for systemic mycosis. Part II: Complement fixation test. Panamerican Health Organization, 1972.

80. Kaufman, L.; Huppert, M.; Fava-Neto, C.; Negroni, R.; Restrepo, A. Manual of standardized serodiagnostic procedures for systemic mycosis. Part I: Agar gel immunodiffusion tests. Panamerican Health Organization, 1972.

81. Kaufman, L.; Standard, P.G. Specific and rapid identification of medically important fungi by exoantigen detection. Annu. Rev. Microbiol., 41, 209-225, 1987.

82. Khansari, N.; Segre, D.; Segre, M. Diagnosis of histoplasmosis and blastomycosis by an antiglobulin hemagglutination test. Am. J. Vet. Res., 43(12), 2279-2283, 1982.

83. Klite, P.D. The interpretation of agar-gel precipitin reactions in histoplasmosis. J. Lab. Clin. Med., 66(5), 770-787, 1965.

84. Klotz, S.A.; Penn, R.L.; George, R.B. Antigen detection in the diagnosis of fungal respiratory infections. Semin. Respir. Infect., 1(1), 16-21, 1986.

85. Kritski, A.L.; Lemle, A.; de Souza, G.R.; de Souza, R.V.; Nogueira, S.A.; Pereira, N.G.; Bethlem, N.M. Pulmonary function changes in the acute stage of histoplasmosis, with follow-up. An analysis of eight cases. Chest, 97(5), 1244-1245, 1990. 
86. Kwon-Chung, K.J. Sexual stage of Histoplasma capsulatum. Science., 175, 326, 1972.

87. Kwon-Chung, K.J. Perfect state (Emmonsiella capsulata) of the fungus causing large-form African histoplasmosis. Mycologia., 67(5), 980-990, 1975.

88. Land, G.A.; Foxworth, J.H.; Smith, K.E. Immunodiagnosis of histoplasmosis in a compromised host. J. Clin. Microbiol., 8(5), $558-565,1978$

89. Leimann, B.C.Q.; Pizzini, C.V.; Muniz, M.M.; Abuquerque, P.C.; Monteiro, P.C.F.; Reis, R.S.; Almeida-Paes, R.; Lazéra, M.S.; Wanke, B.; Pérez, M.A.; Zancopé-Oliveira, R.M. Histoplasmosis in a Brazilian center: clinical forms and laboratory tests. Rev. Iberoam. Micol., 22, 141-146, 2005.

90. Leland, D.S.; Zimmerman, S.E.; Cunningham, E.B.; Barth, K.A.; Smith, J.W. Variability in commercial histoplasma complement fixation antigens. J. Clin. Microbiol., 29(8), 1723-1724, 1991.

91. Londero, A.T.; Ramos, C.D. The status of histoplasmosis in Brazil. Mycopathologia, 64(3), 153-156, 1978.

92. Luby, J.P.; Southern Jr., P.M.; Haley, C.E.; Vahle, K.L.; Munford, R.S.; Haley, R.W. Recurrent exposure to Histoplasma capsulatum in modern air-conditioned buildings. Clin. Infect. Dis., 41(2), 170-176, 2005.

93. Lynch Jr., H.J.; Plexico, K.L. A rapid method for screening sputums for Histoplasma capsulatum employing the fluorescent-antibody technic. N. Engl. J. Med., 266, 811-814, 1962.

94. Maresca, B.; Kobayashi, G.S. Dimorphism in Histoplasma capsulatum: a model for the study of cell differentiation in pathogenic fungi. Microbiol. Rev., 53(2), 186-209, 1989.

95. Markowitz, H. Antibodies in histoplasmosis. J. Bacteriol., 93(1), 40-46, 1967.

96. Mathisen, D.J.; Grillo, H.C. Clinical manifestation of mediastinal fibrosis and histoplasmosis. Ann. Thorac. Surg., 54(6), 1053-1057; discussion, 1057-1058, 1992.

97. Medoff, G.; Kobayashi, G.S.; Painter, A.; Travis, S. Morphogenesis and pathogenicity of Histoplasma capsulatum. Infect. Immun., 55(6), 1355-1358, 1987.

98. Meleney, H.E. Problems in the histological diagnosis of histoplasmosis. Public Health Monogr., 70(39), 14-16, 1956.

99. Meloan, E.L. Histoplasmosis. Miss. Doct., 29(10), 256-257, 1952.

100. Moffit, G.W.; Morgan, B.H.; Cameron, G.M. The isolation of Histoplasma capsulatum from sputum as a diagnostic procedure. $J$. Lab. Clin. Med., 47(3), 499-502, 1956.

101. Mukunyadzi, P.; Johnson, M.; Wyble, J.G.; Scott, M. Diagnosis of histoplasmosis in urine cytology: reactive urothelial changes, a diagnostic pitfall. Case report and literature review of urinary tract infections. Diagn. Cytopathol., 26(4), 243-246, 2002.

102. Murray, P.R. Comparison of the lysis-centrifugation and agitated biphasic blood culture systems for detection of fungemia. J. Clin. Microbiol., 29(1), 96-98, 1991.

103. Negroni, R.; De Flores, C.I.; Robles, A.M. [Study of serologic cross reactions between the antigens of Paracoccidioides brasiliensis and Histoplasma capsulatum]. Rev. Asoc. Argent. Microbiol., 8(2), 6873, 1976.

104. Pine, L. Morphological and physiological characteristics of Histoplasma capsulatum, 1960, p.40-75.

105. Pine, L. Histoplasma antigens: their production purification and uses. Contrib. Microbiol. Immunol., 3, 138-168, 1977.

106. Pine, L.; Malcolm, G.B.; Gross, H.; Gray, S.B. Evaluation of purified $\mathrm{H}$ and $\mathrm{M}$ antigens of histoplasmin as reagents in the complement fixation test. Sabouraudia, 16(4), 257-269, 1978.

107. Pizzini, C.V.; Zancope-Oliveira, R.M.; Reiss, E.; Hajjeh, R.; Kaufman, L.; Peralta, J.M. Evaluation of a western blot test in an outbreak of acute pulmonary histoplasmosis. Clin. Diagn. Lab. Immunol., 6(1), 20-23, 1999.

108. Poles, F.C.; Lavertine, J.D. Acute disseminated histoplasmosis with a report of a case occurring in England. Thorax, 9(3), 233-241, 1954.
109. Pratt, P.T.; Schwartz, S.O.; Ehrlich, L. Aspiration biopsy of bone marrow as an aid in diagnosis of histoplasmosis; report of a case. Arch. Med. Interna., 85(6), 893-899, 1950.

110. Raman, C.; Khardori, N.; Von Behren, L.A.; Wheat, L.J.; Tewari, R.P. Evaluation of an ELISA for the detection of anti-Histoplasma ribosomal and antihistoplasmin antibodies in histoplasmosis. J. Clin. Lab. Anal., 4(3), 199-207, 1990.

111. Reddy, P.A.; Sutaria, M.; Brasher, C.A.; Christianson, C.S. Disseminated histoplasmosis: Cutaneous (subcutaneous abscess), vesical and prostatic histoplasmosis. South Med. J., 63(7), 819821, 1970.

112. Reiss, E.; Obayashi, T.; Orle, K.; Yoshida, M.; Zancope-Oliveira, R.M. Non-culture based diagnostic tests for mycotic infections. Med. Mycol., 38(Suppl. 1), 147-159, 2000.

113. Richardson, M.D.; Warnock, D.W. Enzyme-linked immunosorbent assay and its application to the serological diagnosis of fungal infection. Sabouraudia, 21(1), 1-14, 1983.

114. Rickerts, V.; Bialek, R.; Tintelnot, K.; Jacobi, V.; Just-Nubling, G. Rapid PCR-based diagnosis of disseminated histoplasmosis in an AIDS patient. Eur. J. Clin. Microbiol. Infect. Dis., 21(11), 821-823, 2002.

115. Saliba, A.; Beatty, O.A. Pulmonary histoplasmosis, importance of diagnostic methods, with report of an early case. JAMA. 173, 902904, 1960.

116. Santiago, A.R.; Hernandez, B.; Rodriguez, M.; Romero, H. [A comparative study of blood culture conventional method vs. a modified lysis/centrifugation technique for the diagnosis of fungemias]. Rev. Iberoam. Micol., 21(4), 198-201, 2004.

117. Santos, M.C.P.; Pedrosa, C.M.S. Inquerito epidemiologico com histoplasmina e paracoccidioidina em Arapiraca-Alagoas. Rev. Soc. Bra. Med. Trop., 23(4), 213-215, 1990.

118. Sarosi, G.A.; Johnson, P.C. Disseminated histoplasmosis in patients infected with human immunodeficiency virus. Clin. Infect. Dis., 14(Suppl. 1), S60-67, 1992.

119. Saslaw, S.; Carlisle, H.N. Histoplasmin-latex agglutination test. II. Results with human sera. Proc. Soc. Exp. Biol. Med., 97(3), 700$703,1958$.

120. Sathapatayavongs, B.; Batteiger, B.E.; Wheat, J.; Slama, T.G.; Wass, J.L. Clinical and laboratory features of disseminated histoplasmosis during two large urban outbreaks. Medicine (Baltimore). 62(5), 263$270,1983$.

121. Schubert, J.H.; Lynch Jr., H.J.; Ajello, L. Evaluation of the agarplate precipitin test for histoplasmosis. Am. Rev. Respir. Dis., 84, 845-849, 1961.

122. Schubert, J.H.; Wiggins, G.L. Preliminary studies of $H$ and $M$ components of histoplasmin for skin tests and serology. Am. Rev. Respir. Dis., 92(4), 640-641, 1965.

123. Sekhon, A.S.; Kaufman, L.; Kobayashi, G.S.; Moledina, N.; Jalbert, M.; Notenboom, R.H. Comparative evaluation of the Premier enzyme immunoassay, micro-immunodiffusion and complement fixation tests for the detection of Histoplasma capsulatum var. capsulatum antibodies. Mycoses, 37(9-10), 313-316, 1994.

124. Smith, C.D. Nutritional factors that are required for the growht and sporulation of Histoplasma capsulatum. Ajello, L., E.W. Chick and M.L. Furcolow (Eds). Histoplasmosis. Proceedings of the Second National Conference, 1971, p.64-70.

125. Smith, C.D. The role of birds in the ecology of Histoplasma capsulatum. In: Ajello, L.; E.W. Chick; M.L. Furcolow. (Eds). Histoplasmosis. Proceedings of the Second National Conference. 140-148, 1971

126. Sones, C.A.; Rotkow, M.J.; Dunn, R.C. Acute disseminated histoplasmosis; report of a case in an adult. J. Iowa State Med. Soc., 45(9), 463-468, 1955.

127. Spencer, W.H.; Chan, C.C.; Shen de, F.; Rao, N.A. Detection of histoplasma capsulatum DNA in lesions of chronic ocular histoplasmosis syndrome. Arch. Ophthalmol., 121(11), 1551-1555, 2003. 
128. Stevens, D.A. Diagnosis of fungal infections: current status. $J$. Antimicrob. Chemother, 49(Suppl. 1), 11-19, 2002.

129. Sweet, G.H.; Cimprich, R.S.; Cook, A.C.; Sweet, D.E. Antibodies in histoplasmosis detected by use of yeast and mycelial antigens in immunodiffusion and electroimmunodiffusion. Am. Rev. Respir. Dis., 120(2), 441-449, 1979.

130. Tenenberg, D.J. Histoplasmin and whole yeast-phase Histoplasma capsulatum as antigen in complement fixation tests on histoplasmosis. Public Health Monogr., 70(39), 150-152, 1956.

131. Toriello, C.; Arjona-Rosado, L.C.; Diaz-Gomez, M.L.; Taylor, M.L. Efficiency of crude and purified fungal antigens in serodiagnosis to discriminate mycotic from other respiratory diseases. Mycoses, 34(3-4), 133-140, 1991.

132. Torres-Rodriguez, J.M.; Ribas-Forcadell, E.; Gascon, J.; Espasa, M. [Diagnostic value of intradermoreaction with histoplasmin in nonendemic areas of histoplasmosis]. Med. Clin. (Barc). 113(1), 37-38, 1999.

133. Torres, M.; Diaz, H.; Herrera, T.; Sada, E. Evaluation of enzyme linked immunosorbent-assay and western blot for diagnosis of histoplasmosis. Rev. Invest. Clin., 45(2), 155-160, 1993.

134. Wheat, J. Histoplasmosis: recognition and treatment. Clin. Infect. Dis., 19(Suppl. 1), S19-27, 1994.

135. Wheat, J. Histoplasmosis in the acquired immunodeficiency syndrome. Curr. Top. Med. Mycol., 7(1), 7-18, 1996.

136. Wheat, J. Histoplasmosis. Experience during outbreaks in Indianapolis and review of the literature. Medicine (Baltimore). 76(5), 339-354, 1997.

137. Wheat, J.; French, M.L.; Kamel, S.; Tewari, R.P. Evaluation of cross-reactions in Histoplasma capsulatum serologic tests. J. Clin. Microbiol., 23(3), 493-499, 1986

138. Wheat, J.; Wheat, H.; Connolly, P.; Kleiman, M.; Supparatpinyo, K.; Nelson, K.; Bradsher, R.; Restrepo, A. Cross-reactivity in Histoplasma capsulatum variety capsulatum antigen assays of urine samples from patients with endemic mycoses. Clin. Infect. Dis., 24(6), 1169-1171, 1997.

139. Wheat, L.J. Diagnosis and management of histoplasmosis. Eur. J. Clin. Microbiol. Infect. Dis., 8(5), 480-490, 1989.

140. Wheat, L.J. Laboratory diagnosis of histoplasmosis: update 2000. Semin. Respir. Infect., 16(2), 131-140, 2001.

141. Wheat, L.J.; Kauffman, C.A. Histoplasmosis. Infect. Dis. Clin. N. Am., 17(1), 1-19, 2003.

142. Wheat, L.J.; Connolly-Stringfield, P.; Kohler, R.B.; Frame, P.T.; Gupta, M.R. Histoplasma capsulatum polysaccharide antigen detection in diagnosis and management of disseminated histoplasmosis in patients with acquired immunodeficiency syndrome. Am. J. Med., 87(4), 396-400, 1989.

143. Wheat, L.J.; Connolly, P.; Durkin, M.; Book, B.K.; Tector, A.J.; Fridell, J.; Pescovitz, M.D. False-positive Histoplasma antigenemia caused by antithymocyte globulin antibodies. Transpl. Infect. Dis., 6(1), 23-27, 2004.

144. Wheat, L.J.; Garringer, T.; Brizendine, E.; Connolly, P. Diagnosis of histoplasmosis by antigen detection based upon experience at the histoplasmosis reference laboratory. Diagn. Microbiol. Infect. Dis., 43(1), 29-37, 2002

145. Wheat, L.J.; Connolly-Stringfield, P.; Williams, B.; Connolly, K.; Blair, R.; Bartlett, M. Diagnosis of histoplasmosis in patients with the acquired immunodeficiency syndrome by detection of Histoplasma capsulatum polysaccharide antigen in bronchoalveolar lavage fluid. Am. Rev. Respir. Dis., 145, 1421-1424, 1992.
146. Wheat, L.J.; Connolly-Stringfield, P.; Blair, R.; Connolly, K.; Garringer, T.; Katz, B.P. Histoplasmosis relapse in patients with AIDS: detection using Histoplasma capsulatum variety capsulatum antigen levels. Ann. Intern. Med., 115, 936-941, 1991.

147. Wheat, L.J.; Connolly-Stringfield, P.; Blair, R.; Connolly, K.; Garringer, T.; Katz, B.; Gupta, M. Effect of successful treatment with amphotericin B on Histoplasma capsulatum variety capsulatum polysaccharide antigen levels in patients with AIDS and histoplasmosis. Am. J. Med., 92, 153-160, 1992.

148. Wheat, L.J.; Connolly-Stringfield, P.A.; Baker, R.L. Disseminated histoplasmosis in the acquired immune deficiency syndrome: clinical findings, diagnosis and treatment, and review of the literature. Medicine (Baltimore). 69, 361-374, 1990.

149. Wheat, L.J.; Kohler, R.; Tewari, R. Diagnosis of disseminated histoplasmosis by detection of Histoplasma capsulatum antigen in serum and urine specimens. N. Engl. J. Med., 314, 83-88, 1986.

150. Wheat, L.J.; Kohler, R.; Tewari, R.; Garten, M.L.; French, M.L.V. Significance of Histoplasma antigen in the cerebroespinal fluid of patients with meningitis. Arch. Intern. Med., 149, 302-304, 1989.

151. Williams, B.; Fojtasek, M.; Connolly-Stringfield, P.; Wheat, J. Diagnosis of histoplasmosis by antigen detection during an outbreak in Indianapolis, Ind. Arch. Pathol. Lab. Med., 118(12), 1205-1208, 1994

152. Wilmer, J.A.; de Vries, R.A.; Meijer, J.W.; Richter, C. [Fibrosing mediastinitis: a rare cause of fever]. Ned. Tijdschr. Geneeskd. 148(11), 530-533, 2004

153. Wynne, J.W.; Olsen, G.N. Acute histoplasmosis presenting as the adult respiratory distress syndrome. Chest, 66, 158-161, 1974.

154.Zancope-Oliveira, R.M.; Bragg, S.L.; Hurst, S.F.; Peralta, J.M.; Reiss, E. Evaluation of cation exchange chromatography for the isolation of M glycoprotein from histoplasmin. J. Med. Vet. Mycol., 31(1), 29-41, 1993.

155.Zancope-Oliveira, R.M.; Bragg, S.L.; Reiss, E.; Peralta, J.M. Immunochemical analysis of the $\mathrm{H}$ and $\mathrm{M}$ glycoproteins from Histoplasma capsulatum. Clin. Diagn. Lab. Immunol., 1(5), 563568, 1994

156.Zancope-Oliveira, R.M.; Bragg, S.L.; Reiss, E.; Wanke, B.; Peralta, J.M. Effects of histoplasmin $M$ antigen chemical and enzymatic deglycosylation on cross-reactivity in the enzyme-linked immunoelectrotransfer blot method. Clin. Diagn. Lab. Immunol., 1(4), 390-393, 1994.

157.Zancope-Oliveira, R.M.; e Silva Tavares, P.M.; de Medeiros Muniz, M. Genetic diversity of Histoplasma capsulatum strains in Brazil. FEMS Immunol. Med. Microbiol., 45(3), 443-449, 2005.

158.Zancope-Oliveira, R.M.; Reiss, E.; Lott, T.J.; Mayer, L.W.; Deepe Jr., G.S. Molecular cloning, characterization, and expression of the M antigen of Histoplasma capsulatum. Infect. Immun., 67(4), 19471953, 1999

159.Zeidberg, L.D.; Ajello, L.; Dillon, A.; Runyon, L.C. Isolation of histoplasma capsulatum from soil. Am. J. Public. Health., 42(8), 930-935, 1952.

160.Zimmerman, S.E.; French, M.L.; Kleiman, M.B.; Wheat, L.J. Evaluation of an enzyme-linked immunosorbent assay that uses ferrous metal beads for determination of antihistoplasmal immunoglobulins G and M. J. Clin. Microbiol., 28(1), 59-64, 1990.

161.Zimmerman, S.E.; Stringfield, P.C.; Wheat, L.J.; French, M.L.; Kohler, R.B. Comparison of sandwich solid-phase radioimmunoassay and two enzyme-linked immunosorbent assays for detection of Histoplasma capsulatum polysaccharide antigen. J. Infect. Dis. 160(4), 678-685, 1989. 